INTERNATIONAL JOURNAL OF MULTIDISCIPLINARY RESEARCH AND ANALYSis

ISSN(print): 2643-9840, ISSN(online): 2643-9875

Volume 04 Issue 03 March 2021

DOI: 10.47191/ijmra/v4-i3-17, Impact Factor: 6.072

Page No.- 329-336

\title{
Learning Economics: Evaluation of Students' Cross-Interest Selection of Economics Subjects
}

\author{
Ni Made Indira Suari ${ }^{1}$, M. Rudi Irwansyah ${ }^{2}$, I Putu Arya Dharmayasa ${ }^{3}$ \\ 1,2,3 Faculty of Economics, Universitas Pendidikan Ganesha, Indonesia
}

\begin{abstract}
The lack of socialization about students' interest will have an impact on the wrong choice of cross-interest learning. Besides, the lack of teaching staff can also affect errors in the choice of cross-interest learning. This research was conducted to determine the level of effectiveness from cross-interest selection in $11^{\text {th }}$ economics students at SMA Negeri 3 Singaraja in the academic year 2020/2021 based on the dimensions of context, input, process, and product. This study used an evaluative research design with a quantitative approach, and a questionnaire used as the research instrument. The population of this study was 245 students of class XI SMA Negeri 3 Singaraja who received economics learning. The sampling technique used was purposive sampling technique in getting a sample of 176 students. Questionnaires, interviews, and documentation was used to collect the data. The questionnaire was analyzed by using Z-score and T-score descriptive tests. Then the results of the analysis were converted into a prototype Glickman quadratic. From the data analysis, the context dimension is positive $(+)$, the input dimension is positive $(+)$, the process dimension is positive $(+)$, and the product dimension is positive $(+)$. These results indicate that the evaluation of the cross-interest selection of $11^{\text {th }}$ grade students on economics subject at SMA Negeri 3 Singaraja in the academic year $2020 / 2021$ is $(++++)$ located in quadrant I. So that it can be interpreted that the implementation of the cross-interest selection program is classified as very effective.
\end{abstract}

KEYWORDS: program evaluation, CIPP, cross-interest selection.

\section{INTRODUCTION}

The national development is an effort carried out by all components of the nation in order to achieve the goals of the state, which is stated in Law No. 25 of 2014 about the national development planning system. In line with this, the objectives of national development are stated in the fourth paragraph of the preamble to the 1945 Constitution. One of the purposes of the national development goals is to make the nation's life smarter. As stated by KH Ma'ruf Amin as vice president of the republic of Indonesia, that the government's achievements as proclaimed in the National Medium-Term Development Plan (RPJMN) 2020-2024 are quite encouraging[1]. In line with this case, Nadiem Makarim, the minister of education and culture, established a policy in the national education sector through the "Independent Learning" program [2].

The curriculum used in Indonesia today is the 2013 curriculum, which established to prepare graduates for future globalization[3]. The 2013 curriculum specifically for SMA/MA mentions two important points that must be followed by each school that implements the 2013 curriculum. The two important points are (1) Students are required to follow general subjects, and (2) Students are required to choose academic specialization subjects. In general subjects, it is explained about the group of subjects whose content and references are developed by the minister of education and culture. Whereas in the academic specialization subject, it is described about the group of subjects that are selected directly by students. The academic specialization subjects are aimed at students in preparation for the later tertiary level [4].

Cross-interest selection is held when students are in the early $10^{\text {th }}$ grade. The selection of cross-interest learning was held by the high school which was based on the student's report card scores at the previous junior high school. Not only in terms of student report cards, there are several schools that conduct tests to determine what cross-interest learning is appropriate and according to the needs of students. Students who choose the social studies concentration are free to choose cross-interest learning with elements of science (biology, physics, and chemistry) and elements of language science (English and Japanese). Likewise, students who choose the science concentration are free to choose cross-interest learning with elements of social studies (economics, sociology, and geography) and elements of linguistics (English and Japanese). Meanwhile, students with a 


\section{Learning Motivation and Parents' Socio-Economic Conditions on College Interest}

concentration of IBB are free to choose cross-interests that contain elements of science (biology, physics, and chemistry) and contain elements of social science (economics, sociology, and geography).

By continuing to do modernization in the world of education, it is necessary to conduct an evaluation in every program that has been launched by the government in order to measure how effective the program has been. [5]stated that evaluation is a process of collecting data to determine the extent, in what way, and how educational goals have been achieved. There are several program evaluation models that can be used, according to the type of activity. [6]stated that the CIPP evaluation model provides a very detailed and broad picture of a project, from the context to the time of its implementation process.

Based on the results of interviews with the civil service teacher, Mr. I Nyoman Sudarsana, S.Pd, it was found that the choice of cross-interest was determined directly by the school, not in accordance with the students' demands. The school did this regulation due to the lack of teaching staff in specialization subjects, especially economic subjects. There were 2 teachers of economics subjects. Meanwhile, other cross-interest subjects such as biology and English, the number of teaching staff is more than 4 people. Based on the results of interviewing students who received cross-interest learning in economics, they said that economic learning was not in accordance with their wishes. They prefer to get learning English rather than learning economics because economic learning is too difficult and not easy to understand. However, there are also some students who get crossinterest learning according to their needs, namely economic learning. Regarding to this aspect, if students get cross-interest learning that is not in accordance with their interests, it will have an impact on the academic achievement of these students. In contrast to students who do have an interest in subjects of specialization in economics, they will easily understand the material so that it will have a good impact on the students' academic achievement.

The recapitulation of student learning achievement based on the value of the Minimum Completeness Criteria (KKM) seen from the report on the learning outcomes of $11^{\text {th }}$ grade students in semester 1 of the 2019/2020 academic year who received cross-interest economic learning, all students who get learning across economic interests as many as 85 people, consisting of 27 students of XI IPA 1 class, 29 students of XI IPA 2, and 29 students of XI IPA 4. Based on the data obtained, 25 people get a score above the KKM with a percentage of $29.41 \%$, while as many as 60 people get a score below the KKM with a percentage of $70.59 \%$. This shows that there is a need for evaluation of cross-interest selection programs in order to improve student academic achievement and make it easier for students to prepare for higher education later.

Due to the existing problems, researchers are interested in conducting research with the title "Evaluation of Students' Cross-Interest Election for Economics Subject in $11^{\text {th }}$ Grade students at SMA Negeri 3 Singaraja in Academic Year 2020/2021".

\section{METHOD}

Researchers conducted research at SMA Negeri 3 Singaraja which is located on Jalan Pulau Natuna Penarukan Singaraja, Buleleng Regency, Bali Province. This study uses an evaluative research design with a quantitative approach, [7]states that evaluative research is intended to measure the success of a particular program, product or activity. The sample in this study were 176 students consisting of some classes: XI IPA 1, XI IPA 2, XI IPA 3, XI IBB 2, and XI IBB 3.

The data source used in this study came from primary data, namely data obtained from answers to questionnaires submitted to respondents to find out how the effectiveness of cross-selection of economic interests in students of XI IPA class and XI IBB class at SMA Negeri 3 Singaraja. Meanwhile, the secondary data is the data of $11^{\text {th }}$ grade students with the concentration of IPA and IBB in SMA Negeri 3 Singaraja. Data collection methods in this study are questionnaires, interviews, and documentation. The answers from the respondents regarding the questions composed of the CIPP evaluation indicator will be scored with a benchmark using a Likert scale. In this study, researchers used a Likert scale modification model with four alternative answers to be used. The score description is marked with the symbol SA (Strongly Agree) is given a score of 4, A (Agree) is given a score of 3 , $\mathrm{D}$ (Disagrees) is given a score of 2, and SD (Strongly Disagrees) is given a score of 1.

Before the questionnaire is distributed, the questionnaire must first pass the instrument trial. Testing the validity of the instruments in this study using the Pearson correlation approach, while the instrument reliability testing used Alpha Cronbach reliability. Both tests were carried out with the help of the SPSS for Windows version 24.0 application. The data analysis technique used in the evaluation of cross-interest selection in class XI on economic lessons uses the Z-score and T-score data analysis techniques using the help of a computer program Microsoft Excel 2013 for windows. After confirming the T-score using the criteria for each component of the CIPP program evaluation, the data is then transformed into the effectiveness level category according to the Glickman prototype, to determine the positive (+) or negative (-) direction of the existing data. The data is then added up between the positive score (+) and the negative score (-). If the number of positive (+) scores is greater than or equal to negative $(-)$ scores then the result will be positive (+). If the number of positive $(+)$ scores is smaller than the negative $(-)$ scores, the result is negative (-). 


\section{Learning Motivation and Parents' Socio-Economic Conditions on College Interest}

\section{RESULT AND DISCUSSION}

Result

Evaluation of the selection of cross-interest students towards economics subject in the context dimension can be measured using four indicators, namely needs, planning, goals, and characteristics. In detail, the results of the cross-interest evaluation in terms of context can be seen in table 1 below.

Table 1. Recapitulation of Calculation Results for Each Indicator in Context Dimensions

\begin{tabular}{|l|l|l|l|l|l|}
\hline \multirow{2}{*}{ No } & \multirow{2}{*}{ Indicators } & \multicolumn{2}{|l|}{ Analysis Results } & \multirow{2}{*}{ Status } \\
\cline { 3 - 6 } & & + & - & Criteria & \\
\hline 1. & Needs & 108 & 68 & + & Positive \\
\hline 2. & Planning & 80 & 96 & - & Negative \\
\hline 3. & Objectives & 81 & 95 & - & Negative \\
\hline 4. & Characteristics & 87 & 89 & - & Negative \\
\hline Result & & & + & Positive \\
\hline
\end{tabular}

Based on table 1, the results obtained from the four indicators in each context dimension are seen from the indicators of the need for a positive score of 108 while a negative score of 68 . From the results of the analysis, the positive score is greater than the negative score in the aspect of needs so that the categorized need indicators can support the cross-selection program of students' interests in economics subject in $11^{\text {th }}$ grade students at SMA Negeri 3 Singaraja in the 2020/2021 academic year. In the aspect of planning, the positive score is 80 while the negative score is 96 . On the objectives aspect, the positive score is 81 , while the negative score is 95 . On the characteristics aspect, the positive score was 87 while the negative score was 89 . Thus, it can be seen that the indicators in the context dimension such as planning indicators, objectives indicators, and characteristics indicators, the number of positive scores is less than the number of negative scores. Therefore, those three indicators are categorized as unable to support the cross-interest selection program of students towards economic subjects in $11^{\text {th }}$ grade students at SMA Negeri 3 Singaraja in the 2020/2021 academic year.

After the raw score on the context dimension is analyzed as a whole into a standard score, it can be presented in table 2 below.

Table 2. Recapitulation of Calculation Results in Context Dimensions

\begin{tabular}{|l|l|l|l|l|l|}
\hline No & \multirow{2}{*}{ Indicators } & \multicolumn{2}{|l|}{ Analysis Results } & Status \\
\cline { 3 - 5 } & & + & - & Criteria & \\
\hline 1. & Context & 95 & 81 & + & Positive \\
\hline Result & & & + & Positive \\
\hline
\end{tabular}

Based on Table 2, the results obtained in the context aspect are a positive score of 95 , while a negative score is 81 . In this case, it shows that the positive score is greater than the negative score, so it can be stated that the context dimension is generally categorized as effective in supporting the cross selection of students' interests in economics subject in $11^{\text {th }}$ grade students at SMA Negeri 3 Singaraja. The context aspect is categorized as effective in supporting the program, because the standard score (T-score) is more dominant and has a positive value (+).

Evaluation of the selection of cross-interest students towards economic subjects in the input dimension can be measured using three indicators, namely human resources, necessary procedures and rules, as well as supporting facilities and infrastructure. In detail, the results of the cross-interest evaluation in terms of input can be seen in table 3 below

Table 3. Recapitulation of Calculation Results for Each Indicator on the Input Dimensions

\begin{tabular}{|l|l|l|l|l|l|}
\hline No & Indicators & \multicolumn{2}{|l|}{ Analysis Results } & Status \\
\cline { 3 - 5 } & & + & - & Criteria & \\
\hline 1. & Human Resources & 73 & 103 & - & Negative \\
\hline 2. & Rules and Procedures & 99 & 77 & + & Positive \\
\hline 3. & Supporting Facilities and Infrastructure & 79 & 97 & - & Negative \\
\hline \multicolumn{7}{l}{ Result } & & + & Positive \\
\hline
\end{tabular}




\section{Learning Motivation and Parents' Socio-Economic Conditions on College Interest}

Based on table 3, the results obtained from the three indicators in each input dimension, seen from the human resource indicator, have a positive score of 73 while a negative score of 103 . From the results of the analysis, the positive score is smaller than the negative score so that the human resource indicator is categorized as unable to support the cross-interest selection program of students towards $11^{\text {th }}$ grade students in economics subject at SMA Negeri 3 Singaraja in the 2020/2021 academic year. In contrast to the required procedures and rules indicators, the positive score is 99 while the negative score is 77 . From the results of the analysis, it was obtained that the positive score was greater than the negative score so that the indicators of procedures and rules needed were categorized as supporting the cross-selection program of student interests in economics subject of $11^{\text {th }}$ grade students at SMA Negeri 3 Singaraja in the 2020/2021 academic year. Regarding to the third indicator (supporting facilities and infrastructure) obtained a positive score of 79 while a negative score of 97 . The results of the analysis show that the positive score is smaller than the negative score, so that the supporting facilities and infrastructure indicators cannot support the crossselection program of students' interests towards $11^{\text {th }}$ grade students in economics subject at SMA Negeri 3 Singaraja in the 2020/2021 academic year. After the raw score on the input dimension is analyzed as a whole into a standard score can be presented in table 4 below.

Table 4. Recapitulation of Calculation Results on Input Dimensions

\begin{tabular}{|l|l|l|l|l|l|}
\hline \multirow{2}{*}{ No } & \multirow{2}{*}{ Indicator } & \multicolumn{3}{|l|}{ Analysis Results } & Status \\
\cline { 3 - 5 } & & + & - & Criteria & \\
\hline 1. & Input & 94 & 82 & + & Positive \\
\hline Result & & + & Positive \\
\hline
\end{tabular}

Based on table 4, the results obtained on the input dimension, a positive score of 94 while a negative score of 82 . The results of the analysis show that the positive score is greater than the negative score, so it can be stated that the input dimensions are generally categorized as effective in supporting the cross selection of students' interests in economics subject in $11^{\text {th }}$ grade students at SMA Negeri 3 Singaraja in the 2020/2021 academic year. The input dimension is categorized as effective in supporting the program, because the standard score (T-score) is more dominant and has a positive value $(+)$.

The Evaluation of the selection of cross-interest students towards economics subject in the process dimension can be measured using two indicators, namely program implementation and program measurement. In detail, the results of the crossinterest evaluation in terms of process can be seen in table 5 below.

Table 5. Recapitulation of Calculation Results for Each Indicator in Process Dimensions

\begin{tabular}{|l|l|l|l|l|l|}
\hline \multirow{2}{*}{ No } & Indicators & \multicolumn{2}{|l|}{ Analysis Results } & Keterangan \\
\cline { 3 - 5 } & & + & - & Criteria & \\
\hline 1. & Program Implementation & 114 & 62 & + & Positive \\
\hline 2. & Program Measurement & 106 & 70 & + & Positive \\
\hline Result & & + & Positive \\
\hline
\end{tabular}

Based on table 5, the results obtained from the two indicators in each process dimension are seen from the indicators of program implementation with a positive score of 114 while a negative score of 62 . In line with the program measurement indicator, the positive score is 106 while the negative score is 70 . From the two indicators, the results of the analysis of positive scores were greater than the negative scores, so that the two indicators were categorized as supporting the cross-selection program of students' interests in economics subject in $11^{\text {th }}$ grades students at SMA Negeri 3 Singaraja in the 2020/2021 academic year. After the raw score on the process dimension is analyzed as a whole into a standard score can be presented in table 6 below.

Table 6. Recapitulation of Calculation Results on Process Dimensions

\begin{tabular}{|l|l|l|l|l|l|}
\hline No & \multirow{2}{*}{ Indicators } & \multicolumn{2}{|l|}{ Analysis Results } & \multirow{2}{*}{ Status } \\
\cline { 3 - 5 } & & + & - & Criteria & \\
\hline 1. & Process & 91 & 85 & + & Positive \\
\hline Results & & + & Positive \\
\hline
\end{tabular}

Based on table 6, the results obtained on the process dimension are a positive score of 91 while a negative score is 85 . From these results, it shows that the positive score is greater than the negative score, so it can be stated that the process 


\section{Learning Motivation and Parents' Socio-Economic Conditions on College Interest}

dimensions are generally categorized as effective in supporting the cross selection of students' interests in economics subject in $11^{\text {th }}$ grade students at SMA Negeri 3 Singaraja in the 2020/2021 academic year. The process dimension is categorized as effective in supporting the program, because the standard score (T-score) is more dominant with positive $(+)$ values.

The Evaluation of the selection of cross-interest students towards economic subjects in the product dimension can be measured using three indicators, namely the achievement of program objectives, process suitability, and the impact on the program. In detail, the results of the cross-interest evaluation in terms of products can be seen in table 7 below.

Table 7. Recapitulation of Calculation Results for Each Indicator on Product Dimensions

\begin{tabular}{|c|c|c|c|c|c|}
\hline \multirow[t]{2}{*}{ No } & \multirow[t]{2}{*}{ Indicators } & \multicolumn{3}{|c|}{ Analysis Results } & \multirow[t]{2}{*}{ Status } \\
\hline & & + & - & Criteria & \\
\hline 1. & The achievement of program's objectives & 64 & 112 & - & Negative \\
\hline 2. & Process suitability & 111 & 65 & + & Positive \\
\hline 3. & The impact on the program & 95 & 81 & + & Positive \\
\hline \multicolumn{4}{|c|}{ Result } & + & Positive \\
\hline
\end{tabular}

Based on table 7, the results obtained from the three indicators in each product dimension, seen from the indicators of achievement of program objectives, obtained a positive score of 64 while a negative score of 112 . From the results of this analysis, the positive score is smaller than the negative score so that the indicators of the achievement of the program objectives can not support the cross-selection program of students' interests in economics subject of $11^{\text {th }}$ grade students at SMA Negeri 3 Singaraja in the 2020/2021 academic year. In contrast to the process suitability indicator, it gets a positive score of 111 while a negative score of 65 . In line with the previous indicators, the impact indicator for the program received a positive score of 95 while a positive score of 81 . From the results of the two indicators, a positive score was greater than the negative score, so that the two indicators were categorized as supporting the cross-interest selection program for $11^{\text {th }}$ grade students on economics subject at SMA Negeri 3 Singaraja in the 2020/2021 academic year. After the raw score on the product dimensions is analyzed as a whole into a standard score, it can be presented in table 8 below.

Table 8. Recapitulation of Calculation Results on Product Dimensions

\begin{tabular}{|l|l|l|l|l|l|}
\hline \multirow{2}{*}{ No } & \multirow{2}{*}{ Indicators } & \multicolumn{2}{|l|}{ Analysis Results } & \multirow{2}{*}{ Status } \\
\cline { 3 - 6 } & & + & - & Criteria & \\
\hline 1. & Product & 96 & 80 & + & Positive \\
\hline Result & & & + & Positive \\
\hline
\end{tabular}

Based on table 8 , the results obtained on the product dimension are a positive score of 96 while a negative score is 80. From this it shows that the positive score is greater than the negative score, so it can be stated that the product dimensions are categorized as effective in supporting the cross selection of students' interests in economics subject of $11^{\text {th }}$ grade students at SMA Negeri 3 Singaraja in the 2020/2021 academic year. The product dimension is categorized as effective in supporting the program, because the standard score (T-score) is more dominant with positive (+) values.

So the overall dimensions of the context, input, process, and product produce a score $(++++)$. To find out the effectiveness of the cross-interest selection program of students on economic subjects in class XI at SMA Negeri 3 Singaraja in the 2020/2021 academic year, it can be explained in the following figure 1.

Based on Figure 1, it shows the CIPP value is in positive terms (++++). If converted into the Glickman prototype quadrant, then the evaluation of the cross-interest selection of $11^{\text {th }}$ grade students in economics subject at SMA Negeri 3 Singaraja in the academic year $2020 / 2021$ is located in the first quadrant (I) with very effective information. The Glickman prototype quadrant quadrant I means that the context dimension is effective, the input dimension is effective, the process dimension is effective, and the product dimension is effective. Thus, the evaluation of the cross-interest selection of $11^{\text {th }}$ grade students in economics subject at SMA Negeri 3 Singaraja in the academic year 2020/2021 is classified as very effective. 
Learning Motivation and Parents' Socio-Economic Conditions on College Interest

\begin{tabular}{|l|l|}
\hline II. Efective & I. Very effective \\
Process-Product Input Context & Process-Product Input Context \\
CIPP & CIPP \\
++++ & ++++ \\
++-+ & \\
+-++ & \\
-+++ & \\
\hline IV. Not very effective & III. Not so effective \\
Process-Product Input Context & Process-Product Input Context \\
CIPP & CIPP \\
---- & --++ \\
& --++ \\
& -+-- \\
& +--- \\
& ++- \\
& +-++ \\
& --++ \\
& -+-+ \\
& +-+ \\
& -++- \\
& \\
\hline
\end{tabular}

\section{Discussion}

Based on an evaluative study, this research shows that the evaluation of the cross-selection of students' interests in economics subject of $11^{\text {th }}$ grade students at SMA Negeri 3 Singaraja in the academic year 2020/2021 is in the very effective category $(+++$ + ). This is because each existing dimension shows positive results with the effective category. In the context dimension, the results of the study show that of the four indicators used in the study, only the indicators of needs show positive results. Meanwhile, the other three indicators show negative results. This is because the needs of students for economic learning play a very big role in their lives. Irma Seni Astiningsih as a student said that the need for economic learning was very much needed to facilitate them at a higher level later. [8]states that the context dimension is categorized as effective because the program implemented is in accordance with the needs of the respondent. Program planning is one indicator that does not yet support the effectiveness of the cross-interest selection evaluation on economic subjects. Based on the findings in the field, the planning done by the teacher before teaching is still far from perfect. This can be seen from the way teachers teach who only uses textbooks, without preparing other teaching materials such as learning videos or student worksheets. Not only that, one of the students, Adinda Mutiara said that the subject teacher when teaching only used the lecture method so that students felt sleepy. As described [9]Appropriate learning methods are needed by students so that in the future students are more motivated so as to create a conducive learning environment. Therefore, good planning needs to be done to have a good impact on the program. The government has also planned how the planning should be followed by each school that implements a cross-interest selection program. In line with this, [10]said that the Ministry of Education and Culture has clearly regulated how the procedure for selecting cross-interests starts from planning to opening cross-interest learning for students. The objectives and characteristics of the program also do not support the effectiveness of the evaluation of cross-interest selection programs on economic subjects. Adinda Mutiara Safitri as a resource person said that there are still many IBB class students who do not yet know the characteristics and goals of studying economics. Therefore, it is necessary to conduct socialization related to the characteristics of students so that there are no errors in the selection of learning and it is hoped that students can determine goals in learning the lessons they have chosen.

In the input dimension, the results showed that of the three indicators used in the study, only one indicator showed positive results followed by two indicators that were negative. Overall, the input dimensions produce positive data with effective categories. This is because the procedures and rules needed by the program are very dominant and are in accordance with the criteria issued by the government and can be implemented by the school. The school has implemented the rules and procedures stated in the Permendikbud 2014 and there is no violation of rules and procedures that could have a negative impact on the school. Human resources are one of the indicators that do not yet support the effectiveness of the evaluation of cross-interest selection on economic subjects. This is because students who get learning across economic interests have very low self-esteem. 


\section{Learning Motivation and Parents' Socio-Economic Conditions on College Interest}

Based on the results of interviews with Irma Seni, students are still reluctant to submit opinions or ask questions regarding material they do not understand. Human resources can not only be seen from students, but teachers who teach can affect how the students' human resources are. As stated [11] that there are still many teachers who are not yet professional in carrying out their duties. Therefore, reliable resources are one of the keys to the formation of better human resources. Facilities and infrastructure are one of the indicators that do not yet support the effectiveness of the evaluation of cross-interest selection on economic subjects. This is because the school has not provided facilities and infrastructure that support the learning process in schools such as no teaching aids (LCD projectors), uncomfortable classrooms, and the lack of online media provision when online learning is taking place. [12]stating that the facilities and infrastructure owned by an institution are still below the program standards, it is necessary to make efforts to improve the completeness of the facilities and infrastructure so that they are in accordance with the determined standards.

The process dimension consists of two indicators with each positive result. This is because the implementation of the program and program measurement in the evaluation of the selection of students' interests in economic subjects have been carried out in accordance with the regulations issued by the Minister of Education and Culture. One of the rules issued by the Permendikbud is the preparation of RPP before the learning process takes place. Not only that, teachers of economics always follow the rules and procedures set by the school, by following the existing regulations, teachers of economics are sure that students will be conducive when the teaching and learning process takes place. In line with this [13] explain the implementation of the learning program can stick to PP. 14 of 2017 regarding the standard of the process, in which it explains the implementation of good learning must be based on the lesson plan and syllabus and students can achieve basic competencies in every learning material. Program measurement is one indicator that can support the evaluation of cross-interest selection of economic subjects. This can be seen from the learning outcomes obtained by students. The facts obtained on the evaluation of cross-interest selection of economic subjects, students can quickly answer questions given by subject teachers accompanied by giving awards in the form of praise so that students are more motivated in answering questions. Based on research results [14]states one way to turn on students in the learning process in order to create active students by giving awards to students.

In the product dimension, the results show that of the three indicators used in the study, only one indicator shows negative results followed by two indicators that are positive. This is because the achievement of program objectives has not supported the evaluation of the cross-selection of students' interests in economic subjects. Based on the narrative of Mr. Sudarsana as an economics subject teacher, he said that even though students were able to take economic lessons, to take part in competitions outside of school, students at SMA Negeri 3 Singaraja were still unable to compete with superior schools in Singaraja Regency. Agree with this [15]states that there are four factors that can affect student learning achievement, namely (1) student psychological factors, (2) community environmental factors, (3) school environmental factors, (4) learning support factors, (5) family environmental factors, and (6) school time factor. The suitability of the process and the impact that arises for the program are two indicators that support the evaluation of the selection of cross-interest among students in economic subjects. The suitability of the process in the program has been running optimally by sticking to the regulations that have been issued by the Ministry of Education and Culture as well as the internal regulations issued by the school. [16]stated that economics is a tool used to change unintelligent behavior to be smart about meeting their daily needs. Agreeing with this, Adinda Mutiara said that by studying economics, Adinda can prioritize important things and can manage the needs of her life. Therefore, the selection evaluation program across the interests of students in economic subjects has a good impact on the program and can support the effectiveness of the program.

The results of this study are in accordance with the research [17]which shows that each component of the CIPP is positive and is located in quadrant $\mathrm{I}$. So, it can be concluded that the evaluation of the cross-interest selection of $11^{\text {th }}$ grade students in economics subject at SMA Negeri 3 Singaraja in the academic year 2020/2021 runs very effectively.

\section{CONCLUSION}

Based on the results of findings and discussion, it can be concluded that the evaluation of the cross-interest selection of $11^{\text {th }}$ grade students towards economics subjects at SMA Negeri 3 Singaraja in the academic year 2020/2021 in terms of the context is categorized as effective. Second, the evaluation of the cross-interest selection of $11^{\text {th }}$ grade students in economics subject at SMA Negeri 3 Singaraja in the 2020/2021 academic year in terms of input is categorized as effective. Third, the evaluation of the crossinterest selection of students in the economic subjects of class XI at SMA Negeri 3 Singaraja in the 2020/2021 academic year in terms of the process is categorized as effective. Fourth, the evaluation of the cross-interest selection of students on economic subjects in class XI at SMA Negeri 3 Singaraja in the academic year 2020/2021 in terms of the effective product category. 


\section{Learning Motivation and Parents' Socio-Economic Conditions on College Interest}

\section{REFERENCES}

1) A. Muhammad, “Capaian Pembangunan Nasional Membanggakan Sebelum Terjadinya Wabah Covid-19," Liputan6, Jakarta, 2020.

2) H. Y. Enggar, "4 Gebrakan Merdeka Belajar Mendikbud Nadiem, Termasuk Penghapusan UN," Kompas, Jakarta, 2019.

3) H. Karli, "Perbedaan Kurikulum Tingkat Satuan Pendidikan2006 dan Kurikulum 2013 Untuk Jenjang Sekolah Dasae," J. Pendidik. Penabur, vol. 1, no. 22, pp. 84-89, 2014.

4) Permendikbud, Learning in primary and secondary education. Regulation of the Minister of Education and Culture of the Republic of Indonesia Number 103 of 2014, 1-11., 2014.

5) S. Arikunto, Dasar-dasar Evaluasi Pendidikan Edisi 2. Jakarta: Bumi Aksara, 2012.

6) R. A. Muhammad, Evaluasi Pengelolaan Diklat Teknis. Surabaya: Uwais Inspirasi Indonesia, 2019.

7) Salim dan Haidir, Penelitian Pendidikan : Metode, Pendekatan, dan Jenis Edisi Pertama. Jakarta: KENCANA, 2019.

8) I. W. D. Ariawan, "Evaluasi Program Bank Sampah Sibuh Nirmala Di Desa Kedisan Kecamatan Kintamani Kabupaten Bangli," JUPE, vol. 08, no. 01, pp. 22-30, 2020.

9) A. Widayati, “Metode Mengajar Sebagai Strategi Dalam Mencapai Tujuan Belajar Mengajar," J. Pendidik. Akunt. Indones., vol. 3, no. 1, pp. 66-71, 2004.

10) A. Riafadilah and L. Dewi, “Evaluasi terhadap implementasi lintas minat dalam kelompok peminatan di SMA/MA Kecamatan Lembang," J. Penelit. Ilmu Pendidik., vol. 11, no. 2, pp. 129-133, 2019.

11) S. Raibowo and Y. E. Nopiyanto, "Evaluasi Pembelajaran Pendidikan Jasmani Olahraga \& Kesehatan Pada SMP Negeri SeKabupaten Mukomuko Melalui Pendekatan CIPP," J. Pendidik. Kesehat. Rekreasi, vol. 06, no. 02, pp. 146-165, 2020.

12) E. Tilawati and Y. Sastrawijaya, "Evaluasi Program Full Day Di Sekolah Islam Terpadu ( Studi Evaluatif Menggunakan Model Cipp Di Sd It Dinamika Bogor )," pp. 730-747, 2019.

13) Yoga Budi Bhakti, "Evaluasi Program Model CIPP pada Proses Pembelajaran IPA," JIPFRI J. Inov. Pendidik. Fis. dan Ris. IIm., vol. 1, no. 2, pp. 75-82, 2017.

14) I. S. Wulandari, "Pengaruh Pemberian Reward And Punishment Terhadap Motivasi Belajar Siswa Dalam Pembelajaran Passing Bawah Bola Voli (Studi pada Siswa Kelas VIII SMP Negeri 1 Yosowilangun Lumajang)," J. Pendidik. Olahraga dan Kesehat., vol. 02, no. 03, pp. 599-604, 2014.

15) D. R. Suwardi, "Faktor-faktor Yang Mempengaruhi Hasil Belajar Siswa Kompetensi Dasar Ayat Jurnal Penyesuaian Mata Pelajaran Akuntansi Kelas XI IPS Di SMA Negeri 1 BAE Kudus," Econ. Educ. Anal. J., vol. 01, no. 02, 2012.

16) A. F. Sahroh, "Pengaruh Literasi Ekonomi Dan Tingkat Penggunaan Media Sosial Terhadap Minat Berwirausaha Mahasiswa Fakultas Ekonomi Di Universitas Negeri Surabaya," J. Pendidik. Ekon., vol. 6, no. 3, pp. 2018-215, 2018.

17) I. K. A. Widiana, "Evaluasi Program Bantuan Dana Bergulir Pada Empat Koperasi Penerima Program Bantuan Dana Bergulir Di Kabupaten Buleleng Tahun 2014," J. Pendidik. Ekon. Undiksha, vol. 09, no. 01, 2017. 